\title{
PENINGKATKAN HASIL BELAJAR BAHASA INDONESIA MELALUI MODEL PEMBELAJARAN INTERAKTIF PADA SISWA KELAS III SDN 05 KABUPATEN MUKOMUKO
}

\author{
Harmaini \\ SD Negeri 05 Kabupaten Mukomuko, Mukomuko, Indonesia \\ Posel : $\underline{\text { harmaini12@gmail.com }}$
}

\begin{abstract}
In the cycle of learning improvement studies conducted in class III SD Negeri 05 Mukomuko City by using interactive learning models on Indonesian subjects, teachers did not optimize learning so that some students were still found to be less active in learning. While in cycle I, these deficiencies were overcome by improving learning from prasiklus with the implementation of maximum interactive learning. In prasiklus, there are still students who have not been involved in learning, so in the first cycle, the teacher tries to get students involved by optimizing group discussions and group presentations. Based on the results of improved learning that has been carried out on Indonesian Language class III subjects at SD Negeri 05 Kota Mukomuko, it has been shown to show progress. This can be seen from the increase in student learning outcomes at each meeting. So that it can be concluded that it has succeeded in improving the learning outcomes of Indonesian students in grade III SD Negeri 05 Kota Mukomuko with a cooperative learning model
\end{abstract}

Keywords: learning outcomes, interactive learning, learning and learning

\begin{abstract}
Abstrak : Pada prasiklus penelitian perbaikan pembelajaran yang dilakukan di kelas III SD Negeri 05 Kota Mukomuko dengan menggunakan model pembelajaran interaktif pada mata pelajaran Bahasa Indonesia, guru kurang mengoptimalkan pembelajaran sehingga sebagian siswa masih ditemukan kurang aktif dalam pembelajaran. Sementara pada siklus I, kekurangan tersebut diatasi dengan melakukan perbaikan pembelajaran dari prasiklus dengan pelaksanaan pembelajaran interaktif secara maksimal. Pada prasiklus, masih ada siswa yang belum terlibat dalam pembelajaran, sehingga pada siklus I, guru mengusahakan siswa terlibat dengan mengotimalkan diskusi kelompok dan presentasi kelompok. Berdasarkan hasil perbaikan pembelajaran yang telah dilakukan pada mata pelajaran Bahasa Indonesia siswa kelas III SD Negeri 05 Kota Mukomuko, maka sudah terlihat menunjukan kemajuan. Hal tersebut terlihat dari peningkatan hasil belajar siswa pada setiap pertemuuan. Sehingga dapat disimpulkan telah berhasil meningkatkan hasil belajar Bahasa Indonesia siswa kelas III SD Negeri05 Kota Mukomuko dengan model pembelajaran kooperatif
\end{abstract}

Kata Kunci : hasil belajar, pembelajaran interaktif, belajar dan pembelajaran 


\section{Pendahuluan}

Guru adalah orang yang paling berperan dalam menciptakan sumber daya manusia yang berkualitas dan dapat bersaing di zaman teknologi. Peningkatan mutu pendidikan menjadi tanggungjawab semua pihak yang terlibat dalam pendidikan. Guru merupakan ujung tombak dalam pendidikan dasar. Guru SD Negeri 05 Kota Mukomuko dalam setiap pembelajaran selalu menggunakan pendekatan, strategi, dan metode pembelajaran yang dapat memudahkan siswa memahami materi yang diajarkannya, tetapi masih sering terdengar keluhan dari para guru di lapangan tentang materi pelajaran yang terlalu banyak dan keluhan kekurangan waktu untuk mengajarkannya semua.

Berdasarkan hasil pengamatan, pelaksanaan pembelajaran di kelas masih menggunakan model pembelajaran yang kurang bervariatif dan guru cenderung menggunakan model pembelajaran konvesional pada setiap pembelajaran yang dilakukannya. Hal ini disebabkan kurangnya penguasaan guru terhadap model-model pembelajaran yang ada, padahal penguasaan terhadap model-model pembelajaran sangat diperlukan untuk meningkatkan kemampuan profesional guru dan kesesuaian dengan kurikulum.

Fakta menunjukkan masih banyak ditemukan proses pembelajaran yang kurang berkualitas, tidak efisien, dan kurang mempunyai daya tarik bahkan cenderung membosankan sehingga hasil belajar yang dicapai tidak optimal. Hal ini dapat dilihat dari hasil belajar Bahasa Indonesia siswa kelas III di SD Negeri05 Kota Mukomuko. Untuk itu, guru perlu meningkatkan mutu pembelajarannya dimulai dari rancangan pembelajaran yang baik dengan memperhatikan tujuan, karakteristik siswa, materi yang diajarkan, dan sumber belajar yang tersedia.

Dari keseluruhan siswa, terdapat 8 orang (40\%) siswa yang telah tuntas, sementara 12 orang $(60 \%)$ lainnya masih di bawah KKM. Oleh karena itu, perlu diterapkan pembelajaran yang dapat meningkatkan hasil belajar siswa. Pembelajaran yang perlu dilaksanakan adalah pembelajaran yang melibatkan siswa dalam proses belajar. Salah satu model pembelajaran yang melibatkan siswa dalam proses belajar adalah pembelajaran interaktif.

Model pembelajaran interaktif dikenal dengan nama pendekatan pertanyaan anak. Pembelajaran ini dirancang agar siswa bertanya kemudian menemukan jawaban pertanyaan mereka sendiri (Faire \& Cosgrove dalam Harlen, 1992). Meskipun anak-anak mengajukan pertanyaan dalam kegiatan bebas, pertanyaan-pertanyaan tersebut akan terlalu melebar dan seringkali kabur sehingga kurang terfokus. Guru perlu mengambil langkah khusus untuk mengumpulkan, memilah, dan mengubah pertanyaanpertanyaan tersebut ke dalam kegiatan khusus.

Belajar merupakan salah satu bentuk perilaku yang penting bagi kelangsungan hidup manusia. Belajar membantu manusia menyesuaikan diri dengan lingkungannya. Dengan adanya proses belajar inilah manusia bertahan hidup. Belajar secara sederhana dikatakan sebagai proses perubahan dari belum mampu menjadi sudah mampu dan terjadi dalam jangka waktu tertentu. Perubahan secara relatif bersifat tetap dan tidak hanya terjadi pada perilaku yang saat ini tampak tetapi juga pada perilaku yang mungkin dilakukan di masa mendatang.

Belajar merupakan proses yang ditandai oleh adanya perubahan tingkah laku pada diri seseorang. Perubahan tingkah laku tersebut menyangkut perubahan yang bersifat pengetahuan, keterampilan, maupun nilai sikap. Slameto (1995: 2) menyatakan bahwa "belajar adalah suatu proses usaha yang dilakukan seseorang untuk memperoleh suatu perubahan tingkah laku yang baru secara keseluruhan". 
Volume 1, Nomor 1, Januari 2019

ISSN 2655-3031 (P)

ISSN 2655-7851 (O)

Haryono (2001:7) mengemukakan pelaksanaan model pembelajaran interaktif, yaitu (a) mengidentifikasi tujuan-tujuan yang akan dipelajari oleh siswa, (b) mendiagnosa latar belakang siswa, (c) penstrukturan materi atau menyusun materi secara sistematis untuk mempermudah siswa memahami materi yang akan dipelajari, (d) menyajikan advance organizers (meninjau dan menyusun materi baru yang dipelajari dan menghubungkan materi itu dengan materi yang telah ada sebelumnya), (e) menyajikan progressif diferentiation (pemisahan konsep-konsep atau simpulan-simpulan yang umum dan abstrak ke dalam sub-sub rangkaian yang lebih spesifik dan konkret), dan (f) menyajikan integratif reconciliation. Tujuan pembelajaran interaktif adalah untuk membantu siswa menemukan materi yang baru dan menghubungkannya dengan materi yang telah ada sebelumnya.

Berdasarkan pendapat di atas, dapat disimpulkan bahwa dalam model pembelajaran interaktif guru harus merancang pembelajaran yang membuat siswa aktif mengkonstruksi pengetahuannya. Sebelum memulai pembelajaran guru harus mengidentifikasi tujuan-tujuan yang akan dipelajari siswa, lalu mencari tahu seberapa jauh pengetahuan siswa tentang materi baru yang akan dipelajari, menyusun materi secara sistematis, dan selanjutnya merancang pembelajaran yang memancing siswa membentuk materi baru dengan menghubungkan dengan materi yang telah ada sebelumnya. Pelaksanaan fase-fase yang dijelaskan oleh Haryono di atas pada penelitian ini terlihat saat siswa mengerjakan kegiatan siswa yang ada dalam LKS.

Depdiknas (2003: 3), menyatakan bahwa hasil belajar siswa yang diharapkan adalah kemampuan lulusan yang utuh yang mencakup kemampuan kognitif, psikomotor, dan afektif. Kemampuan kognitif adalah kemampuan berfikir secara hierarki yang terdiri atas pengetahuan, pemahaman, aplikasi, analisis, sintesis, dan evaluasi. Kemampuan psikomotor berkaitan dengan kemampuan gerak (keterampilan) dan terdapat dalam pelajaran praktikum. Kemampuan afektif siswa meliputi perilaku sosial, sikap, minat, disiplin, dan sejenisnya.

Hasil belajar merupakan kemampuan yang dimiliki siswa setelah mengalami proses belajar. Hasil belajar dapat dilihat dari perubahan tingkah laku dari siswa setelah terjadi proses belajar mengajar. Perubahan tersebut terdapat dalam bentuk perubahan terhadap ilmu pengetahuan, sikap, keterampilan, dan sebagainya. Siswa yang berhasil dalam belajar adalah siswa yang memperoleh prestasi baik sesuai dengan indikator yang ditetapkan oleh guru sebelum proses belajar mengajar berlangsung.

Berdasarkan kutipan di atas, dapat disimpulkan bahwa hasil belajar yang diinginkan dalam pembelajaran adalah hasil belajar kognitif, afektif, dan psikomotor. Siswa dikatakan sukses dalam belajar jika siswa sudah memperlihatkan hasil belajar kognitif, afektif, dan psikomotor yang baik. Dalam kurikulum, penilaian hasil belajar ini dikelompokkan menjadi 3 aspek, yaitu: kemampuan pemahaman konsep, kemampuan penalaran dan komunikasi, dan kemampuan pemecahan masalah.

\section{Metode Penelitian}

Penelitian ini menggunakan metode penelitian tindakan kelas yang terdiri atas 2 siklus yang saling berkesinambungan. Dimulai dari prasiklus, siklus 1, dan yang terakhir adalah siklus 2. Berikut ini adalah penjabaran dari metode pelaksanaan penelitiannya.

\section{Prasiklus}

a. Perencanaan

Pada siklus pertama guru merancang langkah-langkah pembelajaran yang akan dilakukan agar proses pembelajaran lebih aktif dan kreatif sehingga hasil belajar siswa meningkat. Adapun langkah-langkah yang akan dilakukan diantaranya adalah sebagai berikut. 
Volume 1, Nomor 1, Januari 2019

ISSN 2655-3031 (P)

ISSN 2655-7851 (O)

1) Menetapkan jadwal pelaksanaan penelitian.

2) Memilih materi yang akan menjadi pembelajaran dalam penelitian.

3) Menyusun Rencana Pelaksanaan Pembelajaran (RPP).

4) Melakukan bimbingan dengan kepala sekolah untuk membantu dalam pelaksanaan Penelitian Tindakan Kelas.

5) Menyiapkan evaluasi.

b. Pelaksanaan

Pelaksanaan merupakan kelanjutan dari perencanaan yang telah disusun dengan memperhatikan masalah yang timbul. Ada beberapa langkah yang ditempuh, yaitu:

1) Guru menjelaskan materi pembelajaran.

2) Guru memberikan soal-soal latihan tentang pembelajara yang telah dilaksanakan.

3) Siswa mengerjakan latihan secara kelompok.

4) Guru meminta siswa mengumpulkan hasil kerjanya.

5) Guru mengevaluasi hasil kerja siswa dan membahas secara bersama-sama dengan siswa.

6) Guru memberikan pujian pada kelompok yang nilainya baik.

\section{c. Pengamatan}

Pengamatan bertujuan untuk mengamati proses pembelajaran yang dilakukan apakah berjalan dengan baik berdasarkan tujuan atau tidak.

\section{d. Refleksi}

Dari kegiatan prasiklus yang dilakukan pada mata pelajaran Bahasa Indonesia di kelas III SD Negeri 05 Kota Mukomuko, terlihat bahwa guru belum melibatkan siswa secara aktif dalam pembelajaran, serta metode yang digunakan kurang bervariasi.

\section{Siklus I}

a. Perencanaan

1) Mengidentifikasi masalah yang ditemukan.
2) Menganalisis dan merumuskan masalah.

3) Merancang model Pembelajaran interaktif.

4) Mendiskusikan penerapan model pembelajaran interaktif dengan kepala sekolah.

5) Menyiapkan perangkat pembelajaran dan instrumen.

6) Menyusun kelompok belajar siswa

7) Merencanakan tugas kelompok

b. Pelaksanaan

1) Melaksanakan langkah-langkah tindakan sesuai dengan yang sudah direncanakan.

2) Menerapkan model pembelajaran interaktif.

3) Melakukan pengamatan terhadap setiap langkah-langkah kegiatan sesuai rencana.

4) Memperhatikan alokasi waktu yang ada dengan banyaknya kegiatan yang dilaksanakan.

5) Mengantisipasi dengan melakukan solusi apabila menemui kendala saat melakukan tahap tindakan.

c. Pengamatan

1) Melakukan diskusi dengan kepala sekolah tentang rencana pengamatan.

2) Melakukan pengamatan terhadap penerapan model pembelajaran interaktif yang dilaksanakan.

3) Mencatat setiap kegiatan dan perubahan yang terjadi saat penerapan model pembelajaran interaktif.

4) Melakukan diskusi dengan supervisor tentang kelamahan-kelemahan atau kekurangan yang dilakukan guru serta memberikan saran perbaikan untuk pembelajaran berikutnya.

d. Refleksi

1) Menganalisis temuan saat melakukan observasi pelaksanaan observasi.

2) Menganalisis kelemahan dan keberhasilan guru saat menerapkan model pembelajaran interaktif dengan kerja kelompok dan mempertimbangkan langkah selanjutnya. 
Volume 1, Nomor 1, Januari 2019

ISSN 2655-3031 (P)

ISSN 2655-7851 (O)

3) Melakukan refleksi terhadap penerapan model pembelajaran interaktif dengan kerja kelompok.

4) Melakukan refleksi terhadap partisipasisiswa dalam pembelajaran.

5) Melakukan refleksi terhadap hasil belajar siswa.

\section{SiklusII}

a. Perencanaan

1) Hasil refleksi dievaluasi, didiskusikan, dan mencari upaya perbaikan untuk diterapkan pada pembelajaran berikutnya.

2) Mendata masalah dan kendala yang dihadapi saat pembelajaran.

3) Merancang perbaikan pada siklus II berdasarkan refleksi siklus I.

b. Pelaksanaan

1) Melakukan analisis pemecahan masalah.

2) Melaksanakan tindakan perbaikan II dengan memaksimalkan penerapan model pembelajaran interaktif dengan kerja kelompok.

c. Pengamatan

1) Melakukan pengamatan terhadap penerapan model pembelajaran interaktif dengan kerja kelompok.

2) Mencatat perubahan yang terjadi.

3) Melakukan diskusi membahas masalah yang dihadapi saat pembelajaran dan memberikan balikan.

d. Refleksi

1) Merefleksi proses pebelajaran interaktif dengan kerja kelompok.

2) Merfleksi hasil belajar siswa dengan penerapan model pembelajaran interaktif dengan kerja kelompok.

3) Menganalisis temuan dan hasil akhir penelitian.

4) Menetapkan rekomendasi terhadap pembelajaran selanjutnya.

Berdasarkan jenis penelitian yang peneliti lakukan, maka data yang telah terkumpul dari hasil belajar diolah dalam bentuk tabel pada masing-masing siklus. Tes akhir belajar digunakan untuk mengukur hasil belajar Bahasa Indonesia siswa setelah menerapkan model pembelajaran interaktif pada pembelajaran Bahasa Indonesia pada siswa kelas III SD Negeri 05 Kota Mukomuko. Setelah hasil tes dinilai, maka nilai tersebut dilihat ketuntasan masingmasing siswa dengan KKM 65. Untuk melihat persentase ketuntasan siswa menggunakan rumus persentase berikut.

$\%$ Ketuntasan $=\frac{\text { ESiswa yang Tuntas }}{\text { Jumlah Siswa }} \times 100 \%$

\section{Hasil dan Pembahasan}

Pada prasiklus penelitian perbaikan pembelajaran yang dilakukan di kelas III SD Negeri 05 Kota Mukomuko dengan menggunakan model pembelajaran interaktif pada mata pelajaran bahasa Indonesia, guru kurang mengoptimalkan pembelajaran sehingga sebagian siswa masih ditemukan kurang aktif dalam pembelajaran. Sementara pada siklus I, kekurangan tersebut diatasi dengan melakukan perbaikan pembelajaran dari prasiklus dengan pelaksanaan pembelajaran interaktif secara maksimal. Pada prasiklus, masih ada siswa yang belum terlibat dalam pembelajaran, sehingga pada siklus I, guru mengusahakan siswa terlibat dengan mengotimalkan diskusi kelompok dan presentasi kelompok.

Selanjutnya, proses pembelajaran pada siklus I juga dievaluasi, sehingga pada siklus II hasil belajar siswa terus meningkat. Pada siklus II guru memotivasi siswa dengan lebih sering memberi pujian dan penguatan kepada siswa yang aktif.

Berdasarkan hasil perbaikan pembelajaran yang telah dilakukan pada mata pelajaran bahasa Indonesia siswa kelas III SD Negeri 05 Kota Mukomuko, maka terlihat menunjukan kemajuan. Hal tersebut terlihat dari peningkatan hasil belajar siswa pada setiap pertemuan, sehingga dapat disimpulkan telah berhasil meningkatkan hasil belajar bahasa Indonesia siswa kelas III SD Negeri 
Volume 1, Nomor 1, Januari 2019

ISSN 2655-3031 (P)

ISSN 2655-7851 (O)

05 Kota Mukomuko dengan model pembelajaran kooperatif.

Berdasarkan hasil perbaikan pembelajaran yang telah dilakukan, terlihat adanya peningkatan rata-rata nilai hasil belajar siswa dari 64,0 pada prasiklus, meningkat menjadi 71,8 dan meningkat lagi menjadi 77,6 pada siklus II. Sementara itu jumlah siswa yang tuntas pada prasiklus $40 \%$, pada siklus I meningkat menjadi $65 \%$ meningkat lagi menjadi $90 \%$ pada siklus II.

\section{Simpulan}

Dari keseluruhan hasil penelitian dengan menggunakan pembelajaran interaktif dalam pembelajaran Bahasa Indonesia pada siswa kelas III SD Negeri 05 Kota Mukomuko, bahwa melalui pembelajaran interaktif ternyata berpengaruh terhadap peningkatan hasil belajar siswa.

Berdasarkan hasil penelitian yang telah dilakukan, maka disarankan hal-hal sebagai berikut.

1. Dalam pelaksanaan program perbaikan pembelajaran guru hendaknya memfokuskan perhatian terhadap kelemahan-kelemahan pembelajaran sebelumnya.

2. Guru merupakan sosok yang selalu ditiru oleh siswa, selain guru juga merupakan ujung tombak peningkatan mutu pendidikan, sehingga guru perlu terus memacu dirinya untuk memperbaiki proses pembelajaran, mampu menciptakan suasana belajar yang kondusif, bersikap inovatif.

3. Guru harus selalu memberikan motivasi belajar, mengembangkan

\section{Daftar Pustaka}

Arifin, Zainal. 1994. Pendekatan Dalam Proses Belajar Mengajar. Bandung: CV. Remaja Karya.

Asikin. 2003. Pembelajaran Matematika Berdasarkan Pendekatan Konstruktivisme dan CTL. Yogyakarta: Kerjasama FMIPA UNY dan Direktorat PLP Depdiknas.

Depdiknas. 2004. Pedoman Penilaian Kelas. Jakarta: Departemen Pendidikan Nasional.

Haryono. 2001. Model Pembelajaran Interaktif. Surabaya: Universitas Negeri Surabaya.

Hasibuan, J.J. Mudjiono. 1988. Proses Belajar Mengajar. Bandung: CV. Remaja Karya.

Hendro Darmodjo, Kaligis, J R E. 1991. Pendidikan Bahasa Indonesia II. Jakarta: Depdikbud, Dirjen Dikti, Proyek Pembinaan Tenaga Kependidikan.

Kemmis, S. dan MC. Toggart R. 1988. TheAction Resesarch Planner. Deakin: Deakin University Australia.

Muliyardi. 2003. Strategi Belajar Mengajar Matematika. Padang: FMIPA UNP.

Sobry Sutikno. 2004. Model Pembelajaran Interaksi Sosial, Pembelajaran Efektif dan Retorika. Mataram: NTB. 